\title{
Interruptions During Pediatric Medication Preparation and Administration
}

\section{Pediatrik Ilaç Hazırlama ve Uygulama Sırasında Yașanan Bölünmeler}

\author{
Suzan Özkan1, Gülseren Kocaman2, Candan Öztürk3 \\ 1 Şifa University Faculty of Health Sciences, Department of Nursing, Izmir, Turkey \\ 2Dokuz Eylül University Faculty of Health Sciences, Department of Nursing, Izmir, Turkey \\ 3/stanbul Sabahattin Zaim University Faculty of Health Sciences, Department of Nursing, Izmir, Turkey
}

\begin{abstract}
Aim: Any interruption or distraction during the process of medication administration might cause a medication error.

Materials and Methods: This observational study examined frequency and reasons of interruptions during preparation and administration of pediatric medications. Two thousand three hundred forty four medication doses were observed during 200 medication administration round. Data regarding the interruptions that occur during the preparation and administration of medications were collected for one calendar year. Frequencies and percentage distributions were calculated for the interruptions as well as their reasons.

Results: An interruption of $36.1 \%$ occurred during this process. Most frequent interruption reasons are mothers, physicians and nurses. Sixty-one errors were made on total of interruptions.

Conclusion: Findings in this study present importance of establishment of clinical and institutional environment for nurses to safe medication administration, in terms of patient safety.

Keywords: Human error, interruption, medication safety, nurses, pediatric
\end{abstract}

öz

Amaç: Ilaç uygulama sürecindeki herhangi bir bölünme ya da dikkat dağınıklı̆ı i laç hatasina neden olabilmektedir.

Gereç ve Yöntemler: Bu araşıtrmada, hemşirelerin ilaç hazrrlama ve uygulama sırasında yaşadkları bölünmelerin sıklığ ve nedenlerinin belirlenmesinde gözlem yöntemi kullanılmıştr. lki yüz ilaç uygulama saatinde 2,344 ilaç uygulama süreci gözlemlenmiş̧ir. llaç hazzrlama ve uygulama sirasinda yaşanan bölünmelere iliş̧kin veriler bir takvim ylinnda toplanmış̧tr. Bölünmelerin sıklık ve yüzde dağlımı yapılmıştr.

Bulgular: llaç uygulama sürecinde \%36,1 oranında bölünme olmuştur. En sık bölünme nedenleri anneler, hekimler ve hemşirelerdir. Bölünmeler nedeni ile 61 hata yapılmıştı.

Sonuç: Bu çalışmanın sonuçları, hemşirenin güvenli ilaç hazırlama ve uygulamasına yönelik klinik ve kurumsal ortamın oluşturulmasının hasta güvenliği açısından önemini ortaya koymaktadır.

Anahtar Kelimeler: Insan hatası, bölünme, ilaç güvenliği, hemşire, pediatri

\section{Introduction}

Any interruption or distraction during the process of medication administration might cause a medication error. Thus, thvis increases the damage risk to pediatric patients, who are considered to form a riskier group in terms of medication administration. In studies where qualitative, retrospective records or reported error reasons were examined, interruptions were depicted as the reason of error (1-3). While there is a limited number of studies looking for the reasons and frequencies of errors through the observation method, there is no study aimed at determining the interruption characteristics in pediatrics.

Westbrook et al. (3) and Palese et al. (4) suggest determining and describing the factors causing interruptions in the work environment for the patient safety as well as for 
ensuring nurses to work under safe conditions. According to Biron et al. (5), further research is needed to better document the contribution of interruptions to medication administration errors as the available evidence is still limited. The suggestion put forward by Biron et al. (5) is of great importance as it shows the necessity of future studies to be conducted in this field. This study was carried out so as to define the frequency and reasons of interruptions that occur during the preparation and administration of medications in the pediatric ward and assess the medication errors caused by these interruptions.

\section{Literature Review}

Most of the studies aiming at determining interruptions during the medication administration have recently been carried out (6). The interruption rates found in these studies which were conducted in different countries were close to one another. Biron et al. (7) observed 374 interruptions $(6.3$ interruption/hour) during 102 medication rounds. Kreckler et al. (8) determined 99 interruptions during 38 rounds and Palese et al. (4) detected 298 interruptions during 56 rounds. Ebright et al. (9) observed the interruptions experienced by nurses in the working environment in their study. Each nurse was monitored for 3 hours, they experienced 7-13 interruptions and each one of them was determined to have experienced approximately 19 interruptions. In the study of McGillis et al. (10), the concept of interruptions in pediatric nurses' working environment was examined and interruptions encountered significantly more frequently while preparing or administering medications were described. It was also reported that some interruptions resulted an increased risk of error.

While Pape (11) observed 484 interruptions in the control group, he observed 64 interruptions in the medsafe group during his interventional study. In another interventional study, human factors techniques were applied to determine interruptions experienced during preparation of paediatric medications through the design of environmental intervention. Interruptions were significantly reduced and staff attitudes towards the situation were considerably improved.

While the reasons of interruptions have varied by the studies, such reasons as nurses, secondary duties, telephone interviews, mising medication are placed on the top. In addition to individual reasons, a significant part of interruptions are caused by system inadequacies. In relation to the medication errors, most studies focus on reasons and solutions. However, only a few of them provide applicable solutions (11). There is a limited number of studies that suggest readjustment of the human factor and working environment with the aim of decreasing the medication errors $(4,11-13)$. According to Reason (14), environmental factors in the system cause errors. It is required to define the factors in the system in order to decrease the interruptions and develop a safe medication administration in the institution.

\section{Materials and Methods}

This study was a part of the project which observed the errors that were made during the pediatric medication administration process (15). In this descriptive study, observation method was used in an attempt to determine the frequency and reasons of interruptions experienced by nurses during the preparation and administration of pediatric medications.

This study was conducted in the pediatric ward of a university hospital. The unit, where the newborns, intensive care, infection and metabolic disease patients between the age range of 0-18 years are hospitalized, has a capacity of 52 beds. The ward having patient rooms with one-five beds is consisted of two corridors. The medications are prepared in the medication room located in the center of the ward. The patient-to-nurse ratios vary between 1:5 and 1:11 according to the patient care intensity in the ward, where 25 nurses work. Each nurse prepares and administers the medications of patients, for whose care they are responsible. Mothers/ caregivers are also present there for 24 hours to help their patients. The sample comprised of 200 medication rounds (10-12-14-18-22-02-06) administered by the nurses who were working in this ward.

Data regarding the interruptions that occur during the preparation and administration of medications were collected for one calendar year. Interruption observation form was used for defining the frequency and reasons of interruptions. This form includes starting and finishing times of the preparation and administration of medications along with spaces where the frequency and reasons of the interruption will be written down. The number and reasons of the nurses' interruptions were recorded in the form in every medication round.

A pre-test was performed in order to assess the usability of the form. Five specialists were consulted in the preparation of the observation form that was drawn up in line with clinical experience and the literature. Necessary corrections were made according to the recommendations of the specialists. A preliminary implementation of the observation form was conducted at the hospital's pediatric surgery unit by a researcher who had experience in research and pediatric clinical training with a second observer having a similar background. The necessary alterations were made in the fields that were found insufficient and a second preliminary implementation was carried out. Frequencies and percentage distributions were calculated for the interruptions as well as their reasons.

Necessary permissions were obtained from the Ethical Committee of the hospital (Dokuz Eylül University, B.30.2..0.70.10.00-3435) and the School of Nursing (Dokuz Eylül University, B.30.2..0.82.00.00/1407) where the study was conducted. Nurses were informed about the objective and method of the study, their questions were answered and their consents were also taken.

\section{Results}

In this study, a total of 2344 medication administration doses were observed during 200 medication administration rounds. While the medication preparation lasted for 


\begin{tabular}{|l|l|l|}
\hline \multicolumn{4}{|l|}{ Table I. Some specifications of the observed medication doses } \\
\hline Variables & $\mathbf{n} \mathbf{( 2 3 4 4 )}$ & $\%$ \\
\hline Interruptions & 847 & 36.1 \\
\hline Interrupted & 1497 & 63.9 \\
\hline Not interrupted & \multicolumn{2}{|l|}{} \\
\hline Medication administration error & 61 & 2.6 \\
\hline Error & 2283 & 97.4 \\
\hline Not error & \multicolumn{2}{|l}{} \\
\hline
\end{tabular}

Table II. Some specifications of the interruptions

\begin{tabular}{|l|l|l|}
\hline Variables & n (847) & \multicolumn{2}{l|}{$\%$} \\
\hline Phase & 616 & 72.7 \\
\hline Preparation & 231 & 27.3 \\
\hline Administration & \multicolumn{2}{|l|}{} \\
\hline Reasons & 188 & 22.2 \\
\hline Mothers/caregivers & 151 & 17.8 \\
\hline Physician & 144 & 17.0 \\
\hline Other nurse & 122 & 14.4 \\
\hline Missing medication & 99 & 11.7 \\
\hline Care management problems & 66 & 7.8 \\
\hline Visitor & 54 & 6.4 \\
\hline Other personel & 23 & 2.7 \\
\hline Emergency situation &
\end{tabular}

approximately 24 minutes, the administration lasted for 36 minutes.

An interruption of $36.1 \%$ occurred during the process of medication administration. Due to interruptions, 61 errors (2.6\%) were reported on a total of 2.344 medication doses. These errors, which are made during the medication preparation, are related to dose and the use of wrong medication (Table I).

Considering the total of 847 interruptions, nurses experienced $72.7 \%$ of them during the medication preparation process and $27.3 \%$ of them during the administration process. Examining the reasons of interruptions, it was observed that the most frequent interruption reasons were mothers $(22.2 \%)$, physicians (17.8\%) and other nurses (17\%). Missing medication in the ward $(14.4 \%)$ and interruptions experienced due to the needs of patient $(11.7 \%)$ were counted among other reasons (Table II).

\section{Discussion}

In this study, a total of 2.344 medication doses were observed during 200 medication administration rounds. The fact that the data were collected in a broad period of time made it easier to define the reasons of interruptions objectively in the system. While the medication preparation lasted approximately for 24 minutes, the administration lasted for 36 minutes. Time averages of medication preparation and administration were found out to be longer when compared to the literature. While a medication administration was reported to take approximately 34 minutes in Biron's (5) study, it was reported to last for 24 minutes in Kreckler et al. (8) study. Longer time averages found in our study could be associated with the nature of our sample since it takes a longer time to prepare and administer pediatric medications when compared to adult doses. Lack of pediatric dose of many medications, administration of doses in small amounts and the physiological features of children affect the medication preparation process of nurses negatively. Future studies aiming at determining the characteristics of interruptions experienced during the preparation and administration of pediatric doses will support the comparableness of our results.

According to the results of our study, nurses experienced interruption in approximately one third of all medication doses. While $3 / 4$ of these interruptions were experienced during the stage of medication preparation, approximately $1 / 4$ of them were encountered during the administration stage. In the study of Biron et al. (5), nurses experienced interruption for at least once in more than half of the medications they prepared. In the study of Westbrook et al. (3), the ratio of interruptions experienced during the stage of medication administration was reported as $53.1 \%$. In the interventional study of Pape (11), which aimed at preventing interruptions during the medication preparation, the control group experienced 484 interruptions while the group where interventions were applied to prevent interruptions experienced 64 interruptions. This result is of paramount importance as it shows that interruptions could be reduced with the help of strategies and preventive interventions.

According to our results, 61 errors (2.6\%) occurred due to interruptions during the preparation of 2344 medication doses. Most of them were related to dose as well as the preparation of wrong medications. According to the results of qualitative studies which examined the reasons of errors, interruptions ranked at the top of the factors leading to errors $(1,15,16)$. In the study of Westbrook et al. $(3)$, which was the first study to assess the relationship between interruptions and medication errors, it was determined that the interruption frequency increases the severity of medication error. The error severity, which is $2.3 \%$ in the absence of interruption, becomes $4.7 \%$ in the presence of four interruptions (3). Our results support the results of Westbrook et al (3). This result is also important as it sets a guide for planning the interventions aiming at preventing interruptions as study results on the ratios and reasons of medication errors made by nurses are utterly limited in the literature.

According to our results, the highest number of interruption was caused by the factor of caregivers. When their children's care management problems came into question, mothers interrupted the medication preparation and administration processes of nurses. While patient-caused interruption was placed on the top in the study of Palese et al. (4), it was reported to cause interruptions by $24.7 \%$ in the 
study of Hedberg and Larsson (17). These interruptions were unpredictable and unanticipated. The number of interruptions could be decreased during the medication preparation with the help of preventive interventions. It is recommended to decrease interruptions and distractions by arranging the medication preparation room as a sterilized cockpit area (14).

One of the most common factors causing interruptions was the nurses themselves. The chitchats of nurses during the medication preparation were reported to constitute one of the primary reasons of error in other studies, as well $(4,16)$. According to the observation data, the nurse obtains information about a study regarding a medication that is not applied before from an experienced nurse or they might prepare it together. The fact that the ward was a general pediatric ward and had a very broad patient profile was thought to influence the medication variety encountered by nurses.

In this study, another important factor leadin to interruptions was found as the late arrival of medications. Late arrival of medications caused interruptions during the preparation and administration phases. Lack of medications is a problem of the system and included among the error reasons (14). System failures, resulting in interruptions during medication administration, cause interruptions more frequently when compared to other nursing activities.

Physician or personnel-origined interruptions were reported to be among the error reasons in many studies $(4,8,11)$. On the other hand, in this study, the nurse experienced interruptions due to the questions of the group or the information they gave. These information are generally related to the changes in patient's medications. Following the physician's visit, the patient's medication doses might change, be terminated or a new medication might start. Nurses should be given information about any change as soon as it occurs for the continuity of treatment and patient safety. Just like the regular medication administration rounds, the medication management strategies might also decrease the interruptions in this area.

Nurses experienced interruptions during medication administration due to other duties related to the patient care such as performing aspiration and recording the liquid follow-up. In the study of Biron et al. (7), the direct patient care interventions were counted among the most frequent reasons of interruption. These were included in the nurse's duties. The interruption of the medication administration process could be prevented by planning the time. Emergency cases such as the patient's resuscitation are unavoidable and unexpected cases. The number of interruptions experienced during medication administration due to such cases is utterly limited.

\section{Limitations}

While the periods of medication preparation and administration were calculated, the interruption period was not calculated.

\section{Conclusion}

This study is the first of its field as it defines the frequency and reasons of interruptions in the field of pediatrics through the method of observation and shows that interruptions lead to errors. According to our results, while the interruptions occur frequently during the medication administration process, the factor causing the highest number of interruptions is caregivers. Although the interruptions might be caused by irrecusable and unpredictable conditions, they can also be caused by resolvable factors in many systems. The results of this study emphasize the importance of establishing an appropriate clinical and institutional environment for nurses to prepare and administer a safe medication to ensure patient safety.

Studies, which examine the factors that contribute to medication errors, comprise a guide for understanding the error reasons. There is a need for immediate solutions for some of the factors that contribute to errors $(14,18)$. Accordingly, the system-centered approach is an accurate step for interventions aiming at decreasing the errors encountered during medication administration. Examining the clinical practices of nurses, it was observed that interruptions were placed at the top among the factors regarding the system. There is a need for further studies assessing the realistic interventions aiming at preventing interruptions.

\section{Ethics}

Ethics Committee Approval: Necessary permissions were obtained from the Ethical Committee of the hospital (Dokuz Eylül University, B.30.2..0.70.10.00-3435) and the school of nursing (Dokuz Eylül University, B.30.2..0.82.00.00/1407) where the study was conducted. Nurses were informed about the objective and method of the study, their questions were answered and their consents were also taken.

Peer-review: External and Internal peer-reviewed.

\section{Authorship Contributions}

Surgical and Medical Practices: Suzan Özkan, Concept: Suzan Özkan, Gülseren Kocaman, Candan Öztürk, Design: Suzan Özkan, Gülseren Kocaman, Data Collection or Processing: Suzan Özkan, Analysis or Interpretation: Suzan Özkan, Gülseren Kocaman, Candan Öztürk, Literature Search: Suzan Özkan, Writing: Suzan Özkan, Gülseren Kocaman, Candan Öztürk.

Conflict of Interest: No conflict of interest was declared by the authors.

Financial Disclosure: The authors declared that this study received no financial support.

\section{References}

1. Mayo AM, Duncan D. Nurse perceptions of medication errors: what we need to know for patient safety. J Nurs Care Qual 2004;19:209-17.

2. Pape TM, Guerra DM, Muzquiz M, et al. Innovative approaches to reducing nurses distractions during medication administration. J Contin Educ Nurs 2005;36:108-16.

3. Westbrook JI, Woods A, Rob MI, Dunsmuir WT, Day RO. Association of interruptions with an increased risk and severity of medication administration errors. Arch Intern 
Med 2010;170:683-90.

4. Palese A, Sartor A, Costaperarı G, Bresadola V. Interruptions during nurses' drug rounds in surgical wards: observational study. J Nurs Manag 2008;17:185-92.

5. Biron AD, Lavoie-Tremblay M, Loiselle CG. Characteristics of work interruptions during medication admininstration. J Nurs Scholarsh 2009;41:330-6.

6. Relihan E, O'Brien V, O'Hara S, Silke B. The impact of a set of interventions to reduce interruptions and distractions to nurses during medication administration. Qual Saf Health Care 2010;19:e52.

7. Biron $A D$, Loiselle CG, Lavoie-Tremblay M. Work interruptions and their contribution to medication administration errors: an evidence review. Worldviews Evid Based Nurs 2009;6:7086.

8. Kreckler S, Catchpole K, Bottomley M, Handa A, Mcculloch P. Interruptions during drug rounds: an observational study. Br J Nurs 2008;17:1326-30.

9. Ebright $\mathrm{P}$, Patterson ES, Chalko BA, Render ML. Understanding the complexity of registered nurse work in acute care settings. J Nurs Adm 2003;12:630-8.

10. McGillis Hall, Pedersen $C$, Hubley $P$, et al. Interruptions and pediatric patient safety. J Pediatr Nurs 2010;25:167-75.

11. Pape TM. Applying airline safety practices to medication administration. Medsurg Nurs 2003;12:77-93.

12. Colligan L, Guerlain S, Steck SE, Hoke TR. Designing for distractions: a human factors approach to decreasing interruptions at a centralised medication station. BMJ Qual Saf 2012;21:939-47.

13. Colligan L, Bass EJ. Interruption handling strategies during paediatric medication administration. BMJ Qual Saf 2012;21:912-7.

14. Reason JT. Human Error. New York, Cambridge University Pres, 2006.

15. Ozkan S, Kocaman G, Ozturk C, Seren S. Frequency of pediatric medication administration errors and contributing factors. J Nurs Care Qual 2011;26:136-43.

16. Stratton KM, Blegen MA, Pepper G, Vaughn T. Reporting of medication errors by pediatric nurses. J Pediatr Nurs 2004;19:385-92.

17. Hedberg B, Larsson US. Environmental elements affecting the decision-making process in nursing practice. J Clin Nurs 2004;13:316-24.

18. Vincent $\mathrm{C}$. Understanding and responding to adverse events. N Engl J Med 2003;13:1051-6. 